\title{
Initial requirements for agricultural universal block-modular energy device of traction class 0.6
}

\author{
Alexander Lavrovi,*, Anatoly Gulyaev ${ }^{1}$, Sergey Popov², Dmitry Komissarov², and Valery \\ Davydov $^{3}$ \\ ${ }^{1}$ Federal Scientific Agro-Engineering Center VIM, 1 Institutsky proezd, 5, Moscow, 109428, Russia \\ ${ }^{2}$ Center of technical cooperation at MGTU named N.E. Baumana, Gospitalniy pereulok, 10, Moscow, \\ 105005, Russia \\ ${ }^{3}$ Belarusian National Technical University, Independence Ave., 65, 1st building, Minsk, 220013, \\ Belarus
}

\begin{abstract}
The state of the tractor industry in Russia is characterized by a deep restructuring of production. This problem is especially acute in the development of modern low-power mobile energy facilities for the mechanization of work in peasant farms. To give a systematic character to the development of this In a promising direction, the initial requirements for an agricultural universal block-modular energy device of traction class 0.6 are proposed.
\end{abstract}

\section{Introduction}

Agricultural activity in Russia is carried out by farms of various forms of ownership and organizational structure, which, according to official statistics, are combined into three large groups or the so-called "Categories": agricultural organizations or enterprises (AE), peasant (farmer) households and personal subsidiary plots of the population. In gross agricultural production, agricultural organizations accounted for $41.4 \%$, peasant farms - $6 \%$ and households - $52.6 \%$.

In view of the importance of the problem of increasing the efficiency of agricultural production, the Government of the Russian Federation has developed a priority national project "Development of the Russian agro-industrial complex", subsequently transformed into the State Program for the Development of Agriculture and Regulation of Agricultural Products, Raw Materials and Food Markets. In these documents, special attention is paid specifically to the development of agricultural production in peasant (farmer) farms (PF) and in personal household (subsidiary) farms of citizens (PHFC), i.e. in the so-called small business forms (SBF).

Currently, the formation and development of peasant (farmer) farms goes in two directions: crop production - production of grain crops, potatoes, vegetables, feed and livestock - production of milk, meat. Their effectiveness is largely determined by the

\footnotetext{
* Corresponding author: vimlavrov@mail.ru
} 
prospects of the selected production area, natural and climatic conditions, the rational organization of the production process and technical equipment.

In peasant farms, small in area of cultivated land, a tractor of traction class 0.6 is the preferred mobile power tool. At the same time, it is important for the owner of the farm to carry out the maximum possible amount of work on his own, since hiring machinery and labor from the outside usually costs a lot more, and sometimes there is no such possibility at all. In these conditions, from the point of view of the owner, it is advisable to have a universal and affordable model (size) of the tractor. At the same time, the universality qualities inherent in the design of the tractor can be fully realized only if it is provided with the necessary set of working machines and implements. In general, the complex of agricultural machines for tractors of class 0.6 has about 211 items that can be used for 87 different technological operations.

Nevertheless, the production of wheeled tractors of traction classes $0.6-0.9$ in the territory of the Russian Federation (RF) is completely discontinued and is only carried out (assembly of imported models. This poses a threat to the very existence of peasant farms. Therefore, the adoption of emergency state measures to stimulate the creation on the territory of the Russian Federation of full-cycle production (using the Russian component base) of low-power tractors, primarily to meet the demand for such products in the framework of national projects [1].

In such a situation, the right choice of a long-term direction of technical policy is necessary, which ensures the competitiveness of domestic tractor equipment both in the domestic and foreign markets. The solution to this problem is possible on the basis of a deep and objective generalization of scientific results obtained in the field of creating new agricultural technologies for agricultural production and crop production, special “agrophilic" propulsion systems, environmentally friendly systems and mechanisms, as well as creating energy and resource-optimal tractors of a new generation [2- 6].

The aim of the study is to formulate and justify the initial requirements for a new generation of universal modular energy agricultural equipment that meets world standards for technical level, economic and ergonomic requirements, versatility and competitiveness.

\section{Materials and methods}

The development of initial requirements for agricultural mobile energy is a complex task that requires a comprehensive analysis:

- the market, the availability and demand for agricultural mobile energy, as well as the direction of development of their design;

- existing and promising technologies and agricultural machinery;

- current standards for mobile energy.

Market, availability and need for agricultural mobile energy and the direction of development of their design.

In accordance with the monitoring conducted by Federal Scientific Agro-Engineering Center VIM, the production of agricultural tractors in Russia decreased from 135.9 thousand tractors in 1990 to 5.8 thousand tractors in 2019, that is 23.4 times. At the same time, the production volume of wheel and caterpillar tractors of traction classes 0.6-0.9 in the territory of the Russian Federation for 2017 respectively amounted to 274 and 3 units, and the production of a full cycle of these traction completely stopped [7]. At the end of 2017, the availability of agricultural mobile energy means of traction classes 0.6-0.9 amounted to 12.5 and 1.3 thousand units, respectively, with a total technological need of 120 thousand units and a total deficit of 116.3 thousand units [8-10]. 
A new technological direction in the development of mobile energy device is to increase energy efficiency in the full life cycle by reducing structural weight, fuel consumption and increasing productivity [11].

The following innovative design and technological solutions are offered.

1) Aggregate-modular and block-modular designing - the transition from individual design of individual types, sizes and modifications of products to the system design of product families from pre-designed and manufactured standard modular components representing a technologically complete production facility is assumed. This approach provides the following advantages: significantly increases the reliability of machines through the use of well-tested and proven components and assemblies; with a small serial production of specific products of machines, a large serial production of components is ensured; sharply reduced time for the development of new models; makes it economically justified to create combined units for specific agro-climatic conditions [12].

2) High-performance mechanical step-gear transmission with gear shifting without breaking the power flow, capable of functioning as a part of wheeled caterpillar tractors;

3) A power take-off system with stepless regulation of operating modes and automatic maintenance of a given speed.

4) Battery-free start-up system based on electric energy storage devices.

5) A replaceable wheel-caterpillar system that ensures compliance with soil exposure standards in all technologically applicable row-spacings of row crops and in all working conditions.

6) Turn around the projection of the center of the rear axle due to the rotation of the steered wheels by an angle of up to $90^{\circ}$ with a track of $1800 \mathrm{~mm}$ or more.

7) The system for changing the internal tire pressure while the tractor is running.

Existing and future technologies and agricultural machines

Energy facilities under development should be "flexible" and adapt well to existing and promising technologies [13].

Mobile energy devices intended for mechanization of work in peasant farms should ensure the implementation of technological operations during the operation of machinetractor units. They should be adapted for use in typical conditions of farming zones with characteristic features of soil and climatic conditions and zonal farming systems.

The nomenclature of agrotechnological qualities of universal mobile energy devices as applied to the field of peasant farms includes the following main indicators.

1 Nominal traction effort of an energy facility is determined by the technological operation being carried out in combination with aggregated working machines and soil conditions.

Calculations showed that the most energy-intensive of technological operations is cultivation, combined with harrowing and leveling. With a machine grip width of $2 \mathrm{~m}$, the required power of the energy facility is in the range $10.8 \ldots 23.2 \mathrm{~kW}$.

2 Range of speeds. When performing technological operations, operating speeds should be different depending on the type of work and specific conditions.

Class 0.6 tractors and self-propelled chassis are currently operating at speeds specified by a set of working machines, mainly in the range of $0.9 \ldots 7.5 \mathrm{~km} / \mathrm{h}$, which today can be considered the most likely for units of this type.

3 Track of width is one of the most significant indicators for universal energy device. Its value should ensure, first of all, the implementation of the basic technological operation is sowing. At different stages of the technological process, various sowing schemes are applied, into which a tractor or other energy source must fit. 
According to monitoring data, Track of width should be adjustable in the range of $1200 \ldots 1800 \mathrm{~mm}$, so that the energy tool can work with the row spacing of 45, 50, 55, 60 and $70 \mathrm{~cm}$.

4 The ground clearance of a mobile energy device should ensure patency during technological operations during pre-sowing preparation of the soil, sowing and in certain technological operations for the care of crops in the phases before emergence and seedling and should be at least the ground clearance of working machines $(350 \mathrm{~mm})$.

5 The power take-off shaft must be independent ( 3 pins) and synchronous ( 2 pins).

6 Mounting and aggregation. Mobile energy facilities must ensure functioning with a set of working machines and have the appropriate lifting capacity of the mounted device.

According to existing standards for class 0.6 tractors, the weight of an individual mounted machine must not exceed $15 \%$ of the tractor weight when mounted in front and $25 \%$ when mounted in rear. With a layered hitch, the total mass of the cargo should not exceed $60 \%$.

Working machines, aggregated with class 0.6 tractors and currently used, are by weight in the range from 230 to $500 \mathrm{~kg}$.

Current Standards for Mobile Energy

When developing the initial requirements for agricultural mobile energy facilities, it is necessary to comply with the requirements of current standards and regulations (Table 1).

Table 1. List of standards applicable to agricultural tractors

\begin{tabular}{|l|l|}
\hline Designation & \multicolumn{1}{|c|}{ Title } \\
\hline TP TC 031/2012 & $\begin{array}{l}\text { Technical regulation of the customs union on the safety of agricultural and forestry } \\
\text { tractors and trailers for them. }\end{array}$ \\
\hline GOST 27021 & $\begin{array}{l}\text { Tractors, agricultural and forestry. } \\
\text { Traction classes. }\end{array}$ \\
\hline GOST 12.2.019 & $\begin{array}{l}\text { Occupational safety standards system. Tractors and self-propelled agricultural } \\
\text { vehicles. }\end{array}$ \\
\hline GOST 12.2.120 & $\begin{array}{l}\text { Cabins and workplaces of tractor operators of self-propelled road-building machines. } \\
\text { General safety requirements. }\end{array}$ \\
\hline GOST 17.2.2.05 & $\begin{array}{l}\text { Environment. Atmosphere. Standards and methods for measuring emissions of } \\
\text { harmful substances from the exhaust gases of tractor and combine diesels. }\end{array}$ \\
\hline GOST 17.2.2.02 & $\begin{array}{l}\text { Environment.. Atmosphere. Norms and methods for measuring exhaust smoke from } \\
\text { tractor and combine engines. }\end{array}$ \\
\hline GOST 3480 & Power take off shaft of agricultural tractors. \\
\hline GOST 18509 & Tractor and combine diesels. Bench Test Methods. \\
\hline GOST R41.96 & $\begin{array}{l}\text { Uniform provisions concerning compression ignition engines intended for } \\
\text { installation on agricultural and forestry tractors and off-road equipment regarding the } \\
\text { emission of harmful substances by these engines. }\end{array}$ \\
\hline GOST 26955 & Agricultural machinery. Ground pressure. \\
\hline OST23.1.97 & Piston hydraulic cylinders for tractors. Technical conditions \\
\hline GOST 10677 & Rear attachment. \\
\hline GOST 3481 & Trailer hitch. \\
\hline GOST 3480 & Power take off shaft \\
\hline GOST 19677 & Agricultural tractors. \\
\hline GOST 3940 & Electrical equipment. \\
\hline GOST 8769 & Lighting engineering. \\
\hline GOST 9200 & Auxiliary equipment. \\
\hline GOST 20760 & $\begin{array}{l}\text { Technical diagnostics. Tractors Parameters and quality features of the technical } \\
\text { condition. }\end{array}$ \\
\hline GOST 305 & Fuel and lubricants. \\
\hline GOST 8581 & Fuel and lubricants. \\
\hline GOST 21150 & Fuel and lubricants. \\
\hline & \\
\hline
\end{tabular}




\begin{tabular}{|l|l|}
\hline Designation & \multicolumn{1}{|c|}{ Title } \\
\hline GOST 6572 & $\begin{array}{l}\text { Coatings for paints of tractors and agricultural machines. General technical } \\
\text { requirements. }\end{array}$ \\
\hline GOST 9.303 & Metallic and non-metallic organic coatings. General selection requirements. \\
\hline GOST 15150 & $\begin{array}{l}\text { Machines, devices and other technical products. Executions for various climatic } \\
\text { regions, categories of operating conditions, storage and transportation regarding the } \\
\text { impact of climatic environmental factors. }\end{array}$ \\
\hline GOST 9238 & Transportation. \\
\hline GOST 9.032 & $\begin{array}{l}\text { Unified system of protection against corrosion and aging. Varnish-and-paint } \\
\text { coatings. Groups, specifications and designations. }\end{array}$ \\
\hline GOST 9.104 & $\begin{array}{l}\text { Unified system of protection against corrosion and aging. Varnish-and-paint } \\
\text { coatings. Groups of operating conditions. }\end{array}$ \\
\hline GOST 12.1.003 & Noise. General safety requirements. \\
\hline GOST R15.201 & Industrial and technical products. The main provisions. \\
\hline GOST R52230 & Automotive electrical equipment. General specifications. \\
\hline GOST 15151 & $\begin{array}{l}\text { Machines, devices and other technical products for areas with a tropical climate. } \\
\text { General specifications. }\end{array}$ \\
\hline GOST 20000 & Tractor and combine diesels. General specifications. \\
\hline GOST 20062 & Tractor seat. General specifications. \\
\hline GOST 20228 & Torque converters for trucks, buses and tractors. \\
\hline GOST 21753 & The "man - machine" system. Control levers. General ergonomic requirements. \\
\hline GOST 24925 & Technical diagnostics. Tractors Diagnostic Aptitude \\
\hline GOST 26656 & Technical diagnostics. Controllability. General requirements. \\
\hline GOST 26803 & Industrial tractors. General technical requirements. \\
\hline GOST 27003 & $\begin{array}{l}\text { Reliability in technology. Composition and general rules for setting reliability } \\
\text { requirements. }\end{array}$ \\
\hline $\begin{array}{l}\text { GOST 12.1.005 } \\
\text { SSBT }\end{array}$ & General hygiene requirements for the air of the working area. \\
\hline GOST 12969 & Plates for cars and tractors. Technical requirements. \\
\hline OST 23.1.92 & Gear pumps of volume hydraulic drive. Technical conditions \\
\hline OST 23.1.96 & Hydroallocators for tractors and agricultural machinery. General specifications. \\
\hline
\end{tabular}

\section{Results and discussion}

Based on an analysis of the designs of analogues of mobile energy devices existing on the market, promising directions for the development of their structures, agrotechnical requirements for performing technological operations, various technologies for cultivating crops and economic conditions, the initial requirements for an agricultural block-modular energy tool have been developed.

Destination requirements.

The energy device and its modifications are intended for the preparation of blockmodular technological mobile and stationary machine-tractor units that perform work in small forms of farming (peasant (farmer) farms (peasant farms) and households (H) and in public utilities:

1) in crop production - the cultivation of grain, the cultivation and harvest of vegetables (in open and closed ground), oilseeds, melons, industrial and forage crops, in orchards, in vineyards, on tobacco and tea plantations, in breeding and primary seed production.

2) in animal husbandry - cleaning manure, distributing all widows of feed and mineral additives, laying litter, preparing and preparing feed for feeding, delivering water and watering animals on pastures, caring for pastures, milking animals on pastures and summer camps, cleaning roads, driveways and the territory of farms from snow and garbage, 
loading and unloading and transport work, maintenance and repair of livestock equipment, a range of work on farm and household plots when cultivating crops in farms and households;

3) in forestry - planting and maintenance of forest stands;

4) in public utilities - clearing snow and removing rubbish from roads and sites, cleaning territories, watering roads, caring for green spaces;

5) in the general economic process - loading and unloading, short-distance transportation of goods;

6) in engineering and technical support - technical maintenance of agricultural and municipal machinery.

Key quality indicators (presented in table 2).

Table 2. The main quality indicators of the agricultural universal block-modular energy device of traction class 0.6

\begin{tabular}{|c|c|c|}
\hline \multicolumn{3}{|c|}{ General indicators } \\
\hline Traction class & 0,6 & 0,9 \\
\hline Operational weight, kg & 1500 & 1700 \\
\hline Construction scheme & \multicolumn{2}{|c|}{$\begin{array}{c}\text { System of quick-connect engine technology } \\
\text { modules }\end{array}$} \\
\hline Operating power of the engine, $\mathrm{kW}$ & 22 & 33 \\
\hline \multicolumn{3}{|c|}{ Transmission } \\
\hline Type & \multicolumn{2}{|c|}{ mechanical, step } \\
\hline $\begin{array}{l}\text { Speed forward, km / h: } \\
\text { - technological, } \\
\text { - operating, } \\
\text { - transport. }\end{array}$ & \multicolumn{2}{|c|}{0,6} \\
\hline $\begin{array}{l}\text { Speed back, km / h: } \\
\text { - technological, } \\
\text { - operating }\end{array}$ & \multicolumn{2}{|c|}{$\begin{array}{l}0,6 \\
5,4\end{array}$} \\
\hline Ratio of adjacent gear ratios & \multicolumn{2}{|c|}{1,2} \\
\hline Efficiency & \multicolumn{2}{|c|}{$0,9-0,92$} \\
\hline \multicolumn{3}{|c|}{ System of Power take-off } \\
\hline Location & \multicolumn{2}{|c|}{ front, back, side } \\
\hline Type & \multicolumn{2}{|c|}{ independent, synchronous } \\
\hline Rotation frequency & \multicolumn{2}{|c|}{$\begin{array}{l}540(1000) \text { switchable to synchronous with a } \\
\text { frequency of rotation of } 3.5 \text { and } 6.5 \mathrm{rpm} \text { on } 1 \mathrm{~m} \\
\text { path }\end{array}$} \\
\hline Efficiency & \multicolumn{2}{|c|}{0,96} \\
\hline \multicolumn{3}{|c|}{ Running system } \\
\hline \multirow[t]{2}{*}{ Mower type } & \multicolumn{2}{|c|}{ removable } \\
\hline & wheeled & tracked \\
\hline Maximum pressure on the soil, $\mathrm{kPa}$ & $80-100$ & $50-60$ \\
\hline Conditional traction efficiency & 0,65 & 0,75 \\
\hline Agrotechnical clearance (retoolable), m & \multicolumn{2}{|c|}{$0,25-0,55$} \\
\hline Track (adjustable), mm & \multicolumn{2}{|c|}{$1200-1800$} \\
\hline
\end{tabular}

Environmental requirements.

Environmental safety assessment should be carried out taking into account all stages of the life cycle (ISO 1400 system of standards) with a level of recycled materials of at least $90 \%$ by weight.

Emission of pollutants with exhaust gas - according to the rules of UNECE Regulation 96. 
The impact of the suspension systems on the soil is in accordance with GOST 26955-86 without moisture restrictions.

Economic requirements.

Mobile energy resources, which, when carrying out technological operations on peasant farms, private households, and in public utilities, form a family as part of a basic universal unit and its specialized equipment should ensure an increase in labor productivity by an average of 4 ... 5 times at least.

Specific “energy" cost (in 2020 prices), thousand rubles / hp no more:

budget economic model 15.0;

business models 25.0 thousand

When calculating economic indicators, one should proceed from the technological need in the park of 30 thousand units (excluding exports).

Requirements for versatility.

The number of agricultural machines aggregated in the complex is 350 pcs. no less

\section{Conclusions}

Based on the studies, the initial requirements for an agricultural universal block-modular energy facility have been developed.

The energy tool developed according to these requirements will provide

- a decrease in the total specific energy consumption of a unit of useful work by 1.4-1.6 times,

- environmental safety,

- competitiveness.

It will also significantly increase the level of marketability and profitability of agricultural production in peasant (farmer) enterprises.

\section{References}

1. Smirnov M.A., Lavrov A.V., Shevtsov V.G. On the need to restore mechanized agricultural production in Russia, National interests: priorities and security, 2018, T. 14, No. 1, S. 48 - 61.

2. Reinhart E.S., Khvostov V.A. Equipment for farms // "Potatoes and waxes", 1991.- No. 1.

3. Reinhart E.S., Khvostov V.A. Machines for harvesting root crops and onions A.O. "Polimag", M., 1995.

4. Izmailov A.Yu., Kryazhkov V.M., Antyshev N.M. and others. The concept of modernizing the fleet of agricultural tractors in Russia for the period until 2020, M .: VIM, 2013. -84 p.

5. Márquez L. Tractores Agricolas: tecnologia y utilización. Madrid: B\&H Grupo Editorial, 2012. pp. 844.

6. Kryazhkov. V.M., Godzhaev Z.A., Shevtsov V.G., Lavrov A.V. Tractor park: state and development direction, Rural mechanic, 2015, No. 9, p 3-5.

7. Production of automotive, tractor and agricultural machinery and components for it by manufacturers in Russia and other CIS countries // Analytical review / OJSC "ASMHolding”. -2009, 2010, 2011, 2012, 2013, 2014, 2015, 2016, 2017, 2019 -№ 12.

8. The methodology for using the conditional conversion factors for tractors, grain and forage harvesters into reference units when determining the requirements for their needs, M: Federal State Institution "Rosinformagroteh", 2009, 56 p. 
9. Kryhkov V.M., Godzhaev Z.A., Shevtsov V.G., Gurylev G.S., Lavrov A.V. The development of the russian agricultural tractor market from 2008 to 2014. COMVEC 2016 SAE, doi: 10.4271/2016-01-8128, 27.09.2016.

10. Shevtsov V., Lavrov A., Izmailov A. and Lobachevskii Y. Formation of Quantitative and Age Structure of Tractor Park in the Conditions of Limitation of Resources of Agricultural Production, SAE: 2015-26-0147, doi: 10.4271/2015-26-0147.

11. Godzhaev Z.A., Lavrov A.V., Shevtsov V.G., Zubina V.A. About the choice of the technological direction of the development of the agricultural mobile energy system // News of MSTU "MAMI", 2020, No. 1 (43), 35-41.

12. N.V. Krasnoshchekov, A.A. Artyushin, N.M. Antyshev, Block-modular principles for the creation of agricultural machinery, M .: Informationgrotech, 1998, $104 \mathrm{p}$.

13. Initial requirements for basic machine technological operations in crop production: [collection], Ministry of Villages. households Ros. Federation, Feder. village agency. household; [developed by: V.P. Elizarov et al.], M .: Rosinformagroteh, 2005 (Type. FGNU Rosinformagroteh), 270 p. 